\title{
Extractive Spectrophotometric Determination of Niobium (V) Using 3- Hydroxy-2-(4'-Methoxyphenyl)-4-Oxo-4H-l-Benzopyran as a Complexing Agent
}

\author{
Nivedita Agnihotri ${ }^{1}$ and Rajesh Agnihotri ${ }^{*}, 2$ \\ ${ }^{I}$ Department of Chemistry, National Institute of Technology, Kurukshetra-136 119, Haryana, India \\ ${ }^{2}$ University Institute of Engineering \& Technology, Kurukshetra University, Kurukshetra-136 119, Haryana, India
}

\begin{abstract}
Hydroxy-2-(4'-methoxyphenyl)-4-oxo-4H-1-benzopyran (HMPB) forms a yellow colored (1:3) complex with niobium (V), which is extracted into dichloromethane from 1.04-4.40 molL ${ }^{-1} \mathrm{HClO}_{4}$ solution showing an absorption maximum at $398-412 \mathrm{~nm}$ (figure curve A: $1.0 \mu \mathrm{g} \mathrm{Nb} \mathrm{ml}^{-1}$ versus blank; curve B: blank versus DCM) with Beer's law range of $0-1.3 \mu \mathrm{g} \mathrm{Nb} \mathrm{ml}^{-1}$, molar absorptivity of $3.764 \times 10^{4} \mathrm{~L} \mathrm{~mol}^{-1} \mathrm{~cm}^{-1}$ and the detection limit as $0.036 \mu \mathrm{g} \mathrm{ml} \mathrm{m}^{-1}$. The results are highly reproducible with a standard deviation of \pm 0.0037 . The linear regression equation is $\mathrm{Y}=0.399 \mathrm{X}+0.006$ and the correlation coefficient, $r=1.0004$
\end{abstract}

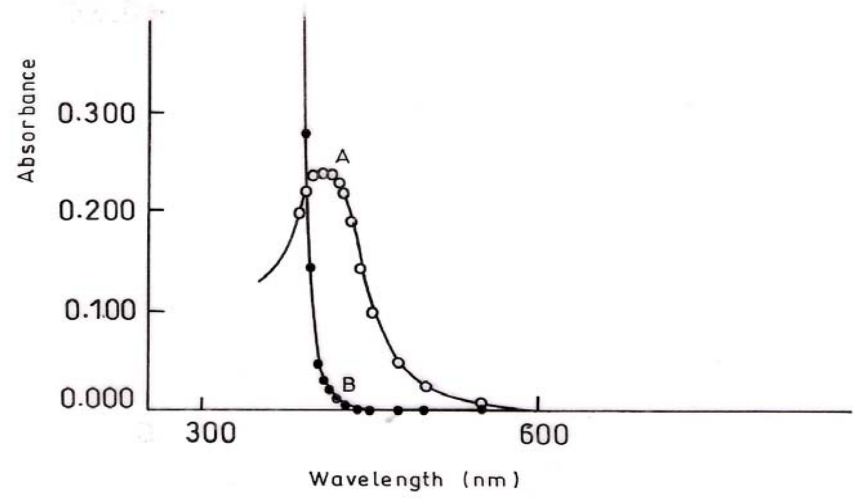

The method is free from the interference of a large number of analytically important elements. The proposed method handles satisfactorily the analysis of several samples of varying complexity.

Keywords: Niobium(V), 3-hydroxy-2-(4'-methoxyphenyl)-4-oxo-4H-1-benzopyran, extraction, spectrophotometric determination.

\section{INTRODUCTION}

An extractive spectrophotometric method is developed for the trace determination of niobium in acidic medium. A yellow (1:3) complex of niobium(V) is formed with 3hydroxy-2-(4'-methoxyphenyl)-4-oxo-4H-1-

benzopyran(HMPB) in perchloric acid medium. The colored species is quantitatively extractable into dichloromethane from $1.04-4.40 \mathrm{~mol} \mathrm{~L}^{-1} \mathrm{HClO}_{4}$ showing an absorption maximum in the region $398-412 \mathrm{~nm}$. Beer's law holds over the niobium concentration range of $0-1.3 \mu \mathrm{g} \mathrm{Nb} \mathrm{ml}^{-1}$, with a molar absorptivity and Sandell's sensitivity of $3.764 \times 10^{4} \mathrm{~L}$ $\mathrm{mol}^{-1} \mathrm{~cm}^{-1}$ and $0.0025 \mu \mathrm{g} \mathrm{Nb} \mathrm{cm}{ }^{-2}$, respectively at $405 \mathrm{~nm}$. The linear regression equation of the method is $\mathrm{Y}=0.399 \mathrm{X}+$ 0.006 and the correlation coefficient, $r=1.0004$. The method is highly reproducible with a standard deviation of \pm 0.0037 and the detection limit $0.036 \mu \mathrm{g} \mathrm{ml}^{-1}$. Out of a number of

*Address correspondence to this author at the University Institute of Engineering \& Technology, Kurukshetra University, Kurukshetra -136 119, Haryana, India; Fax: +911744238967; E-mail: rajniv@sify.com cations, anions and complexing agents studied, only Sn(II) and fluoride interfere even in traces in the method. The method is simple, fast, sensitive, selective and handles satisfactorily the analysis of several samples of varying complexity.

Various existing methods [1-14] of spectrophotometric determination of niobium $(\mathrm{V})$ suffer from interferences from a large number of foreign ions like Ti, V, Mo, W, Pt, Re, U and Ta. The methods are usually time consuming [1,3-5], though sensitivity is slightly improved in a few cases. The highly sensitive and reliable methods for quick determination of niobium such as atomic absorption and atomic emission are not found suitable in routine analysis because of their high cost and the requirement of a separate lamp source for each element to be determined. The literature survey on the methods of extraction and spectrophotometric determination of niobium reported in the past, employing benzopyrans as complexants [3-5,11,14], reveal that there is still a lot more to be done regarding rapidity, selectivity and sensitivity to find their usefulness concerning the analytical chemistry of niobium. With this 
end in view, 3-hydroxy-2-(4'-methoxyphenyl)-4-oxo-4H-1benzopyran(HMPB) has been used for the first time in a spectrophotometric determination system involving niobium in microgram amounts.

\section{EXPERIMENTAL}

Apparatus and reagents: UV-visible (Shimadzu-14002) spectrophotometer with $10 \mathrm{~mm}$ matched glass cells is used for absorbance measurements and spectral studies.

A stock solution of niobium $\left(1 \mathrm{mg} \mathrm{ml}^{-1}\right)$ is prepared by fusing accurately weighed amount $(0.1430 \mathrm{~g})$ of niobium pentaoxide, $\mathrm{Nb}_{2} \mathrm{O}_{5}$, with potassium hydrogen sulphate $(3 \mathrm{~g})$ in a silica crucible. The melt is then dissolved in hot $5 \%$ tartaric acid solution, cooled and made up to the mark with the acid solution in a $(100 \mathrm{ml})$ volumetric flask. The solution thus obtained is standardised gravimetrically with cupferron [15]. Working solutions at $\mu \mathrm{g} \mathrm{ml}^{-1}$ level are prepared fresh by suitable dilution of the stock solution with $2 \%$ tartaric acid solution. Similarly, a standard solution of tantalum (V) $\left(1 \mathrm{mg} \mathrm{ml}^{-1}\right)$ is prepared by fusing $0.1221 \mathrm{~g}$ of $\mathrm{Ta}_{2} \mathrm{O}_{5}$ with $\mathrm{KHSO}_{4}$. Lower concentrations of the metal ion are prepared exactly as for niobium above. The solutions of other metal ions are prepared by dissolving their commonly available chemically pure salts in water or dilute hydrochloric or sulfuric acid to give $\leq 10 \mathrm{mg} \mathrm{ml}^{-1}$ concentration of the ions.

3-Hydroxy-2-(4'-methoxyphenyl)-4-oxo-4H-1-benzopyran $\left(\mathrm{HMPB} ; \mathrm{mp} 234^{\circ} \mathrm{C}\right)$ is prepared by the literature method [16] and dissolved in acetone to give $0.1 \%(\mathrm{w} / \mathrm{v})$ solution. Dichloromethane (RANKEM) is used as such.

Preparation of HMPB: Solutions of 2-hydroxyacetophenone $(0.01 \mathrm{~mol}$ in $30 \mathrm{ml}$ ethanol) and $\mathrm{KOH}(0.03 \mathrm{~mol}$ in $10 \mathrm{ml}$ of ethanol) are mixed and stirred $\left(2 \mathrm{~h}\right.$, below $\left.60^{\circ} \mathrm{C}\right)$ after adding 4-methoxybenzaldehyde $(1.21 \mathrm{ml}=0.01 \mathrm{~mol})$ dropwise. The mass I thus obtained is neutralized with 0.2 mol L $\mathrm{L}^{-1} \mathrm{HCl}$ and crystallized from water and ethanol. Solutions of compound I( $1 \mathrm{~g}$ in $20 \mathrm{ml}$ ethanol), $\mathrm{NaOH}(8 \mathrm{ml}$ of $20 \%$ in ethanol) and $\mathrm{H}_{2} \mathrm{O}_{2}$ (4 ml of 70 volume) are mixed, stirred $\left(2 \mathrm{~h}\right.$, below $\left.10^{\circ} \mathrm{C}\right)$ and neutralized with $\mathrm{CH}_{3} \mathrm{COOH}$. The yellow compound so obtained after crystallization from ethanol and water is HMPB (m.p. $234^{\circ} \mathrm{C}$ )

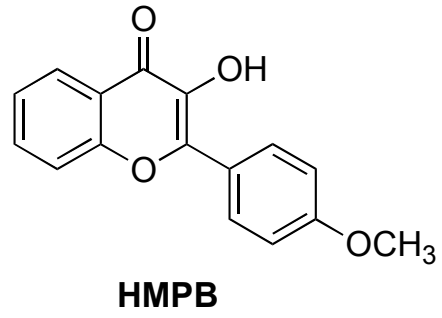

Perchloric acid (Qualigens, "Excelar") $8 \mathrm{~mol} \mathrm{~L}^{-1}$ is prepared by diluting $70 \%\left(11.6 \mathrm{~mol} \mathrm{~L}^{-1}\right)$ acid with deionized water.

Samples: Synthetic samples are prepared by mixing niobium (V) solution with solutions of other metal ions in suitable proportions, as shown in Table $\mathbf{1}$.

Reverberatory flue dust: Flue dust sample $(0.1 \mathrm{~g}$ niobium free) from the copper manufacture unit is mixed with a solution of known niobium content $(1 \mathrm{mg})$ in a silica crucible. It is dried in an oven at $110-120^{\circ} \mathrm{C}$, fused with sodium peroxide $(0.8 \mathrm{~g})$, dissolved in $25-30 \mathrm{ml}$ of hot $2 \%$ tartaric acid solution and the final volume made to $250 \mathrm{ml}$ in a volumetric flask with the same tartaric acid solution. Appropriate aliquots of the resulting solution are taken for the determination of niobium by the proposed method.

Water samples: Water samples $(10 \mathrm{ml}$ each) from tap and well are mixed separately with a known concentration of niobium, $6 \% \mathrm{H}_{2} \mathrm{O}_{2}(1 \mathrm{ml})$ and aqueous ammonia $(2 \mathrm{ml})$. The solution is boiled and evaporated to dryness. The residue is dissolved in 1-2 $\mathrm{mol} \mathrm{L}^{-1} \mathrm{HClO}_{4}$ and niobium determined by the proposed method.

Procedure: To an aliquot of the sample solution containing up to $13 \mu \mathrm{g} \mathrm{Nb}(\mathrm{V})$ and other ions taken in a 100 $\mathrm{ml}$ separating funnel, $1.5 \mathrm{ml}$ of $8 \mathrm{~mol} \mathrm{~L}^{-1} \mathrm{HClO}_{4}$ and $2.0 \mathrm{ml}$ of $0.1 \%$ HMPB solution are added. The whole mixture is diluted to $10 \mathrm{ml}$ with deionised water to bring the final acidity of the aqueous phase to $1.20 \mathrm{~mol} \mathrm{~L}^{-1}$. The contents are mixed gently and then equilibrated once with an equal volume $(10 \mathrm{ml})$ of dichloromethane for $30 \mathrm{~s}$ taking care to release the pressure occasionally through the stop cock. After phase separation the organic extract is passed through Whatman No. 41 filter paper (pretreated with dichloromethane) to remove water droplets. The absorbance of the yellow extract is measured at $405 \mathrm{~nm}$ against the similarly treated reagent blank using $10 \mathrm{~mm}$ glass cells.

In case of samples containing Mo(VI), W(VI) and $\mathrm{Ti}(\mathrm{IV})$, the optimum amounts of masking agents required to be added to the aqueous solution prior to the addition of reagent (HMPB) are: $0.3 \mathrm{ml}$ of $\mathrm{H}_{2} \mathrm{O}_{2}(6 \% \mathrm{w} / \mathrm{v})$; for each of $\mathrm{W}(\mathrm{VI})$ up to $0.03 \mathrm{mg}$, Ti(IV) up to $0.1 \mathrm{mg}$ and $\mathrm{Mo}(\mathrm{VI})$ up to $0.01 \mathrm{mg}$ in a final $10 \mathrm{ml}$ aqueous volume.

Finally, niobium content in various samples is computed from the calibration curve prepared under optimum conditions of the procedure.

\section{RESULTS AND DISCUSSION}

A yellow complex of niobium(V) is formed with HMPB in perchloric acid medium and the complex is quantitatively extractable into dichloromethane. The absorption spectrum of the complex indicates that the maximum lies in the range 398-412 nm where the reagent blank has minimal absorbance (Fig. 1). The absorbance of the complex in the solvent is influenced by the nature and concentration of acids. The effect of different acids on the $\mathrm{Nb}(\mathrm{V})$ complex is studied at $0.2 \mathrm{~mol} \mathrm{~L}^{-1}$ acidity and it is found that the absorbance of the complex decreases in the order $\mathrm{HClO}_{4}>$ $\mathrm{HCl}>\mathrm{CH}_{3} \mathrm{COOH}>\mathrm{H}_{2} \mathrm{SO}_{4}>\mathrm{H}_{3} \mathrm{PO}_{4}$. Therefore, $\mathrm{HClO}_{4}$ medium has been preferred for further studies. It is found that maximum and constant absorbance is obtained when $1.04-4.40 \mathrm{~mol} \mathrm{~L}^{-1}$ of $\mathrm{HClO}_{4}$ is used. Thus $1.20 \mathrm{~mol} \mathrm{~L}^{-1}$ of perchloric acid is selected for further work.

The optimum values of other parameters found for achieving maximum and constant absorbance are: $1.9-2.4 \mathrm{ml}$ of HMPB $(0.1 \% \mathrm{w} / \mathrm{v}$ in acetone) and $10-300 \mathrm{~s}$ equilibration time for $\leq 13 \mu \mathrm{g} \mathrm{Nb}$ per $10 \mathrm{ml}$ aqueous solution (Table 2 ).

A number of water immiscible organic solvents extract the niobium(V) complex in the decreasing order of absorbance as : dichloromethane $>$ 1,2-dichloroethane $>$ chloroform $>$ amyl acetate $>$ amyl alcohol $>$ benzene $>$ 
Table 1. Analysis of Samples by the Proposed Method

\begin{tabular}{|c|c|c|c|c|}
\hline \multirow{2}{*}{ S. No. } & \multicolumn{2}{|c|}{ Sample Composition } & \multicolumn{2}{|c|}{ Nb Found ${ }^{b}$} \\
\hline & Matrix $^{a}$ & $\mathrm{Nb}$ Added $/ \mu \mathrm{g}$ & $\mu \mathrm{g} \pm \mu \mathrm{g}(\mathrm{SD})$ & PAR ${ }^{1}$ Method \\
\hline 1. & $\operatorname{Mn}(2), \mathrm{Co}(2), \mathrm{Cu}(0.1), \mathrm{Zn}(2)$ & 10 & $10.07 \pm 0.07$ & 9.88 \\
\hline 2. & $\mathrm{Os}(0.5), \mathrm{Ba}(1), \mathrm{Au}(0.1)$ & 5 & $5.11 \pm 0.14$ & 5.19 \\
\hline 3. & $\operatorname{Th}(1), \operatorname{Bi}(1), \mathrm{V}(0.05)$ & 7 & $6.84 \pm 0.19$ & 6.91 \\
\hline 4. & $\mathrm{Cr}^{\mathrm{VI}}(0.1), \mathrm{Ce}(1), \mathrm{U}(1)$ & 8 & $8.07 \pm 0.14$ & 8.27 \\
\hline 5. & $\operatorname{Pt}(0.01), \operatorname{Pd}(0.01), \operatorname{Al}(1)$ & 10 & $9.83 \pm 0.08$ & 10.12 \\
\hline 6. & $\mathrm{~W}(0.01), \operatorname{Ti}(0.01), \operatorname{Se}(0.5)^{\mathrm{c}}$ & 5 & $5.19 \pm 0.13$ & 4.94 \\
\hline 7. & $\operatorname{Ta}(0.1), \operatorname{Ir}(0.01), \operatorname{As}(1)$ & 12 & $12.27 \pm 0.14$ & 12.22 \\
\hline 8. & $\operatorname{Mo}(0.01), \operatorname{Mg}(1), \operatorname{Cd}(1)^{\mathrm{c}}$ & 10 & $10.05 \pm 0.14$ & 9.88 \\
\hline 9. & $\mathrm{Cr}^{\mathrm{III}}(0.5), \mathrm{Ni}(2), \mathrm{Sr}(2)$ & 5 & $4.99 \pm 0.07$ & 5.06 \\
\hline \multirow[t]{2}{*}{10.} & Reverberatory flue dust(100) & 10 & $9.93 \pm 0.07$ & 9.75 \\
\hline & & 5 & $5.06 \pm 0.13$ & 5.06 \\
\hline \multirow[t]{2}{*}{11.} & Tap Water & 10 & $10.00 \pm 0.12$ & 10.00 \\
\hline & & 8 & $7.95 \pm 0.08$ & 8.15 \\
\hline \multirow[t]{2}{*}{12.} & Well Water & 12 & $12.05 \pm 0.06$ & 12.10 \\
\hline & & 5 & $5.06 \pm 0.13$ & 4.94 \\
\hline
\end{tabular}

${ }^{a}$ Figure in brackets indicates the amount of the metal ions in $\mathrm{mg}$.

${ }^{\mathrm{b}}$ Average of triplicate analyses.

'In presence of $0.3 \mathrm{ml} \mathrm{H}_{2} \mathrm{O}_{2} 6 \%(\mathrm{w} / \mathrm{v})$.

carbon tetrachloride $>$ toluene. As dichloromethane gives maximum absorbance with a rapid and clear phase separation, it is chosen as the most suitable extractant. The coloured complex of $\mathrm{Nb}(\mathrm{V})$ with $\mathrm{HMPB}$ formed under optimum conditions is stable for more than $1 \mathrm{~h}$ in dichloromethane at $405 \mathrm{~nm}$.

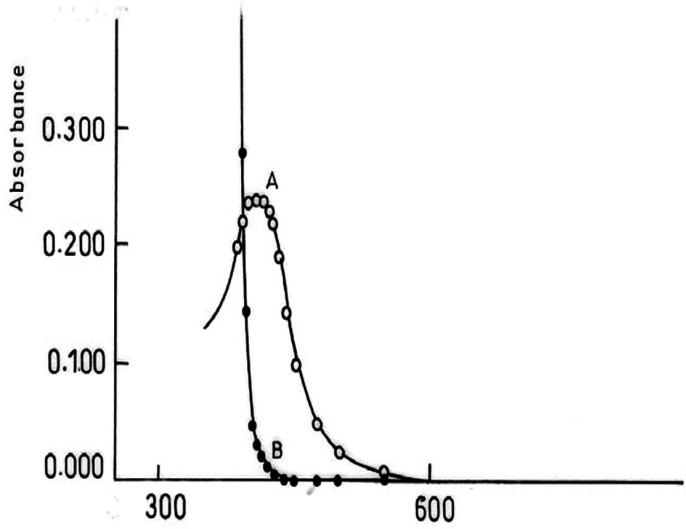

Fig. (1). Absorption Spectrum of $\mathrm{Nb}(\mathrm{V})$ - HMPB complex in dichloromethane. A: $1.0 \mu \mathrm{g} \mathrm{Nb} \mathrm{cm}{ }^{-3}$ measured against reagent blank, B: reagent blank against dichloromethane.

The method obeys Beer's law over the concentration range of $0.0-1.3 \mu \mathrm{g} \mathrm{ml}^{-1} \mathrm{Nb}(\mathrm{V})$. However, the optimum concentration range of niobium $(\mathrm{V})$ that can be measured accurately, as evaluated from Ringbom plot [17] (Fig. 2) is found to be $0.32-1.30 \mathrm{ppm}$. The molar absorptivity and Sandell's sensitivity of the complex at $405 \mathrm{~nm}$ are $3.764 \times$ $10^{4} \mathrm{~L} \mathrm{~mol}^{-1} \mathrm{~cm}^{-1}$ and $0.0025 \mu \mathrm{g} \mathrm{Nb} \mathrm{cm}{ }^{-2}$, respectively. The detection limit of the method is $0.036 \mu \mathrm{g} \mathrm{ml}^{-1}$. Ten replicate determinations containing $1 \mu \mathrm{g} \mathrm{Nb} \mathrm{ml}{ }^{-1}$ give a standard deviation of \pm 0.0037 absorbance unit. The linear regression equation is $\mathrm{Y}=0.399 \mathrm{X}+0.006(\mathrm{Y}=$ absorbance, $\mathrm{X}=\mu \mathrm{g}$ $\mathrm{Nb} \mathrm{ml}^{-1}$ ) and the correlation coefficient, $\mathrm{r}=1.0004$

Stoichiometry of the Complex: Equimolar solutions of niobium and HMPB $\left(2.152 \times 10^{-3} \mathrm{~mol} \mathrm{~L}^{-1}\right)$ are utilized to determine the metal to ligand ratio by Job's method of continuous variations [18]. The absorbance values are measured at two different wavelengths, 405 and $425 \mathrm{~nm}$. The obtained curves are indicative of 1:3 stoichiometry in the extracted species (Fig. 3). This is further confirmed by the mole-ratio method [19] by taking the concentration of niobium as $2.152 \times 10^{-3} \mathrm{~mol} \mathrm{~L}^{-1}$ and measuring the absorbance at two different wavelengths of 405 and $425 \mathrm{~nm}$ (Fig. 4).

From the consideration of the data obtained from the above mentioned parameters, optimum conditions for the system are laid down as already described in the procedure.

Effect of Diverse Ions: Under the optimum conditions of the procedure in $10 \mathrm{ml}$ aqueous volume ( $\mathrm{mg}$ amounts in parentheses), chloride, phosphate, thiourea, EDTA 'disodium salt', sulfosalicylic acid, thiocyanate, bicarbonate, hydrazine sulfate and boric acid (100 each); bromide, ascorbic acid and dithionite ( 80 each); sulfate, nitrate, sulfite, acetate and iodide (50 each); tartrate and citrate (30 each); oxalate (3); glycerol (1 ml) and $\mathrm{H}_{2} \mathrm{O}_{2} 6 \%(\mathrm{w} / \mathrm{v})(0.3 \mathrm{ml})$ do not affect the absorbance of $\mathrm{Nb}(\mathrm{V})$-HMPB complex. However, fluoride interferes even in small amounts.

Among the cations, $\mathrm{Pb}$ (II), $\mathrm{Ca}$ (II), $\mathrm{Ba}$ (II), $\mathrm{Sr}$ (II), $\mathrm{Cd}$ (II), Th (IV), $\mathrm{Hg}$ (II), Mn (II), $\mathrm{Ag}$ (I) and $\mathrm{Mg}$ (II) (10 mg each); Zn (II), Ni (II) and Co (II) (9 mg each); As (III), Bi 
Table 2. Effect of Various Parameters on the Absorbance of Nb-HMPB Complex

\begin{tabular}{|c|c|c|c|c|c|c|}
\hline $\mathrm{HClO}_{4}\left(\mathrm{~mol} \mathrm{~L}^{-1}\right)^{\mathrm{a}}$ & 0.40 & 0.56 & 0.80 & 0.96 & $1.04-4.40$ & \\
\hline Absorbance & 0.190 & 0.215 & 0.240 & 0.260 & 0.280 & \\
\hline $0.1 \%$ HMPB $(\mathrm{ml})^{b}$ & 0.5 & 1.0 & 1.5 & 1.7 & $1.9-2.4$ & 2.5 \\
\hline Absorbance & 0.200 & 0.280 & 0.365 & 0.380 & 0.405 & 0.385 \\
\hline Equilibration time (s) & 0 & 5 & $10-300$ & & & \\
\hline Absorbance & 0.050 & 0.290 & 0.405 & & & \\
\hline
\end{tabular}

Conditions: ${ }^{\mathrm{a}} \mathrm{Nb}(\mathrm{V}): 10 \mu \mathrm{g}, \mathrm{HClO}_{4}=$ variable, $0.1 \% \mathrm{HMPB}=1 \mathrm{ml}$, equilibration time $=30 \mathrm{~s}$, solvent $=$ dichloromethane, aqueous volume $=$ solvent volume $=10 \mathrm{ml},{ }^{\mathrm{b}} \mathrm{HClO}{ }_{4}=1.20$ mol L ${ }^{-1}$; other conditions being the same as in (a) except for the variation in HMPB concentration, also b = 3-hydroxy-2-(4'-methoxyphenyl)-4-oxo-4H-1-benzopyran(HMPB). ${ }^{\mathrm{c}} 0.1 \%$ HMPB in acetone $=2.0 \mathrm{ml}$, other conditions being the same as in (b) except for the variation in equilibration time.

(III), Ce (IV) and Al (III) (5 mg each); U (VI) (4 mg); Be (II), Cr (III), Os (VIII), Cu (II) and Se (IV) (1 mg each); $\mathrm{Cr}$ (VI) (0.5 mg); Ta (V) (0.3 mg); V (V), Zr (IV), Au (III), Pt (IV), Fe (III) and Ir (III) (0.1 mg each); Pd (II) and Ru (III) $(0.05 \mathrm{mg}$ each) cause $<1 \%$ error. Mo (VI), W (VI) and Ti (IV) do not interfere in presence of the masking agents as described under the modified procedure. However, Sn (II) even in traces gives dark yellow color showing high absorbance values and hence interferes seriously.

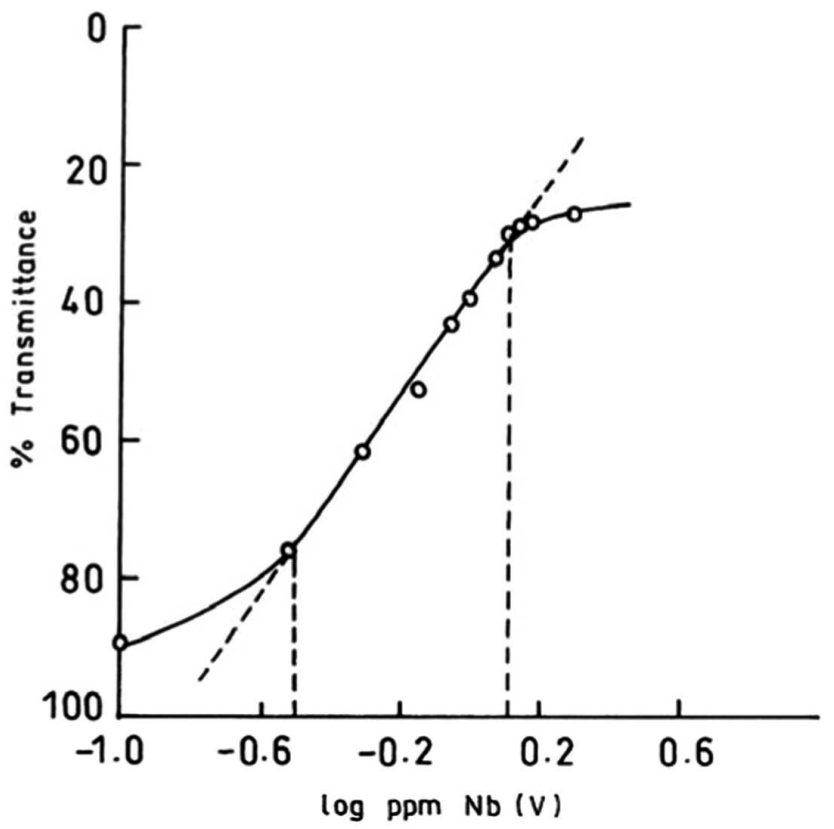

Fig. (2). Ringbom plot for $\mathrm{Nb}(\mathrm{V})$ - HMPB complex.

Applications: The wide applicability of the method is tested by the satisfactory analysis of a variety of synthetic and technical samples containing niobium up to $13 \mu \mathrm{g}$ in the aliquot (Table 1). The proposed method is quite selective for niobium determination in the presence of large number of elements especially $\mathrm{Ti}, \mathrm{V}, \mathrm{Cr}, \mathrm{Mn}, \mathrm{Fe}, \mathrm{Co}, \mathrm{Ni}, \mathrm{Cu}, \mathrm{Zn}, \mathrm{W}$, $\mathrm{Ta}, \mathrm{Zr}, \mathrm{Ce}, \mathrm{Th}, \mathrm{U}, \mathrm{Bi}, \mathrm{Cd}, \mathrm{As}$, alkaline earth and platinum metals, which seriously interfere in most of the existing methods of niobium determination. The proposed method compares favourably with the existing ones (Table 3) and offers the advantages of better simplicity, rapidity, sensitivity and selectivity.

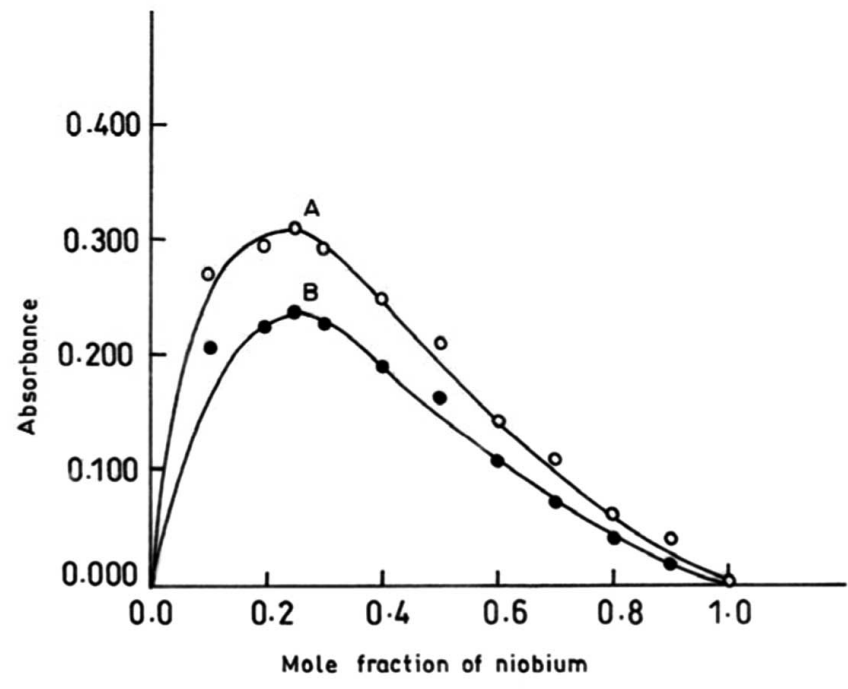

Fig. (3). Job's method of continuous variations. Total concentration $[\mathrm{Nb}]+[\mathrm{HMPB}]=2.15 \times 10-3 \mathrm{~mol} \mathrm{dm}^{-3}$. Curve A: $405 \mathrm{~nm}$, Curve B: $425 \mathrm{~nm}, \mathrm{HClO}_{4}=1.2 \mathrm{~mol} \mathrm{dm}$.

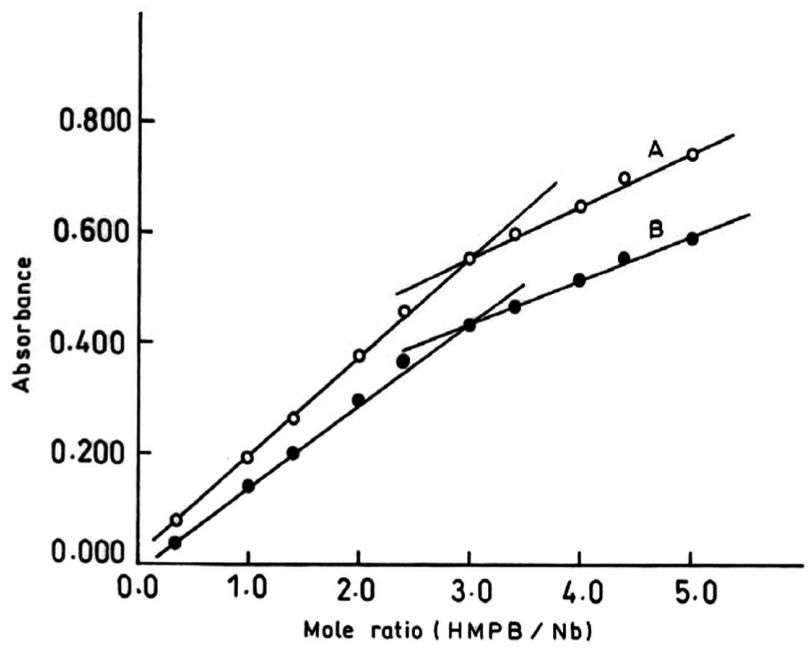

Fig. (4). Mole ratio method. Total concentration of metal ion fixed, $[\mathrm{Nb}]=2.15 \times 10-3 \mathrm{~mol} \mathrm{dm}^{-3}$. Curve A: $405 \mathrm{~nm}$, Curve B: $425 \mathrm{~nm}$. $\mathrm{HClO}_{4}=1.2 \mathrm{~mol} \mathrm{dm}{ }^{-3}$. 
Table 3. Comparison of the Proposed Method of Niobium Determination with Existing Ones

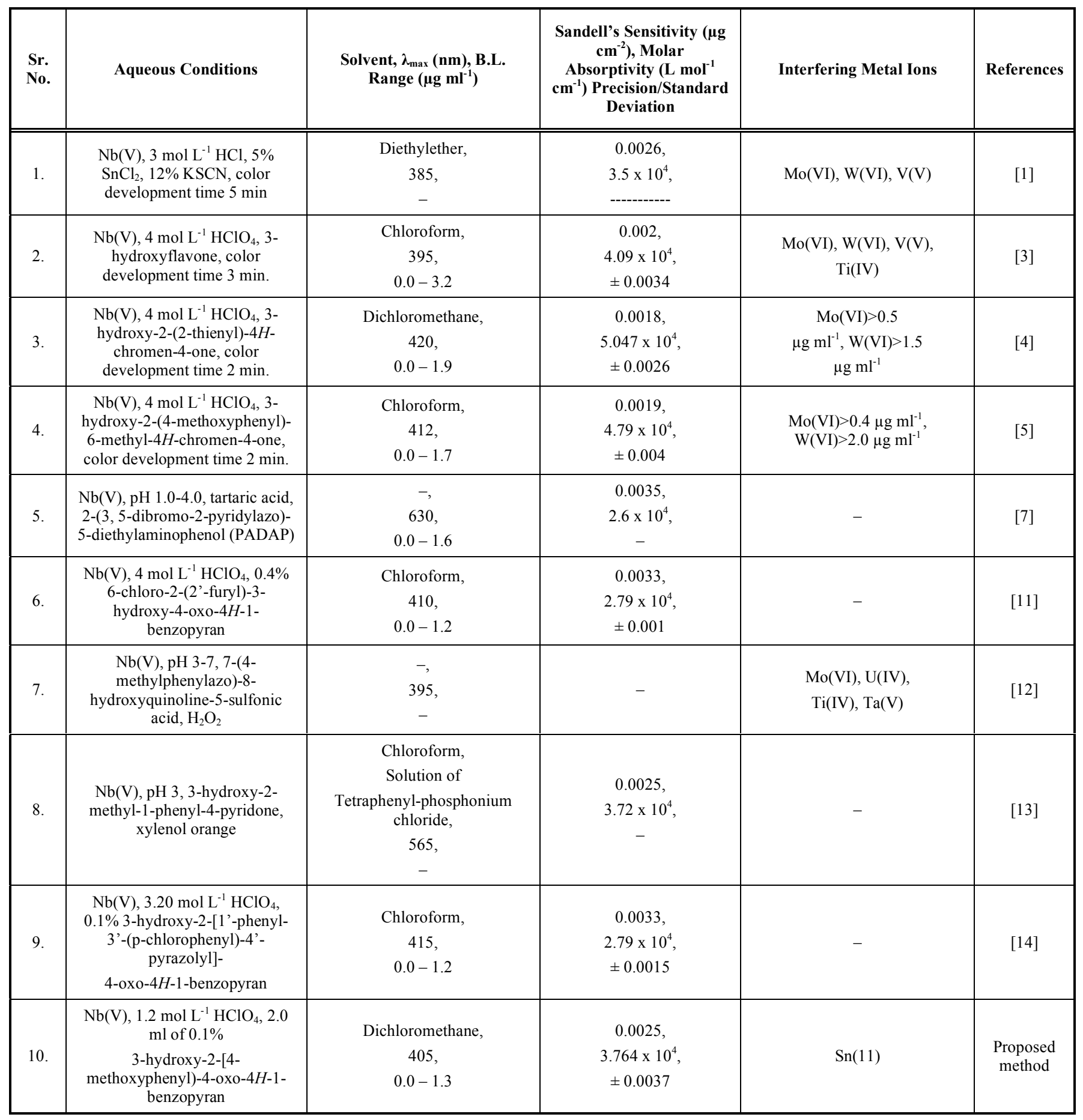

\section{ACKNOWLEDGEMENT}

Our sincere thanks are due to National Institute of Technology, Kurukshetra and to Kurukshetra University, Kurukshetra for providing laboratory facilities.

\section{CONFLICT OF INTEREST}

The authors confirm that this article content has no conflicts of interest.

\section{REFERENCES}

[1] Marczenko, Z. Spectrophotometric Determination of Elements; Wiley: New York, 1986

[2] Sandell, E.B. Colorimetric Determination of Traces of metals, 3rd ed.; Interscience Publ. Inc.: New York, 1959; p. 682

[3] Chakkar, A.K.; Kakkar, L.R. Extractive spectrophotometric determination of niobium (V) using 3-hydroxyflavone. Microchim. Acta, 1995, 117, 137.

[4] Chakkar, A.K.; Kakkar, L.R. Extractive spectrophotometric determination of niobium (V) with 3-hydroxy-2-(2-thienyl)-4Hchromen-4-one. Fresenius J. Anal. Chem., 1995, 351, 720. 
[5] Dass, R.; Mehta, J. R. Extractive spectrophotometric determination of niobium (V) using 3-hydroxy-2-(4-methoxyphenyl)-6-methyl4H-chromen-4-one. Annali. di. Chimica, 1997, 87, 653.

[6] Patel, K.; Menon, S.K.; Agrawal, Y.K. Extraction and micro determination of niobium (V) with N-ó-phenylstyrylacrylohydroxamic acids. Microchem. J., 1996, 53, 158.

[7] Li, H.; Dong, J.; Lin, Y.; Li, J. Photometric determination of niobium with 3,5-dibromo-PADAP-tartaric acid. Beijing Keji Daxue Xuebao, 1996, 18, 96.

[8] Huang, Y.; Zhang, P. Rapid spectrophotometric determination of niobium in steel with 5-Br-PADAP. Lihua Jianyan, Huaxue Fence, 1997, 33, 445 .

[9] Tao, H. Spectrophotometric determination of niobium in $\mathrm{Nb}$ thiocyanate-Rhodamine B system. Yankuang Ceshi, 1998, 17, 44.

[10] Inoue, S.; Mishima, O.; Zhang, Q.; Minami, H.; Uto, M. Spectrophotometric determination of niobium (V) with N-cinnamoyl-N2,3-xylylhydroxylamine and thiocyanate. Anal. Lett., 2001, 34, 2465 .

[11] Agnihotri, N.; Mehta, J.R. A highly selective spectrophotometric determination of niobium (V) using 6-chloro-2-(2'-furyl)-3hydroxy-4-oxo-4H-1-benzopyran as a complexing agent and chloroform as an extractant. J. Indian Chem. Soc., 2003, 80, 837.

[12] Nashine, N.; Mishra, R.K. Extraction-spectrophotometric determination of niobium with thiocyanate and N-hydroxy-N, N'-diphenylbenzamidine. J. Indian Chem. Soc., 1993, 70, 661.
[13] Gojmerac, A.; Galic, N.; Tomisic, V. Formation and extraction of niobium (V) complex with xylenol orange in the presence of 4pyridone derivative. J. Solut. Chem., 2009, 38, 149.

[14] Agnihotri, N.; Raj Kamal; Mehta, J. R. A highly selective spectrophotometric determination of niobium (V) using 3-hydroxy2-[1'-phenyl-3'-(p-chlorophenyl)-4'-pyrazolyl]-4-oxo-4H-1benzopyran as a complexing agent. Annali. di. Chimica, 2006, 96, 479.

[15] Schoeller, W.R.; Powell, A.R. The Analysis of Minerals and ores of the Rare Elements, 3rd ed.; Griffin, London, I955; p. 218.

[16] Algar, J.; Flynn, J. P. A new method for the synthesis of flavonols. Proc. Roy. Irish Acad., 1934, 42B, 1; Oyamada, T. A new general method for the synthesis of the derivatives of flavonols. J. Chem. Soc. Jpn., 1934, 55, 1256.

[17] Ringbom, A. The accuracy of colorimetric analysis methods 1 . Fresenius J. Anal. Chem.,1938, 115, 332.

[18] (a) Job, P. Formation and stability of inorganic complexes in solution. Ann. Chim., 1928, 9, 113. (b) Vosburgh, W.C.; Cooper, G. $\mathrm{R}$. The identification of complex ions in solution by spectrophotometric measurements. J. Am. Chem. Soc., 1941, 63, 437.

[19] Yoe, J. H.; Jones, A. L. Colorimetric determination of iron with disodium-1,2-dihydroxybenzene-3,5-disulfonate.Ind. Eng. Chem. Anal. Ed, 1944, 16, 111 .

Received: April 19, 2012

Revised: May 18, 2012

Accepted: May 19, 2012

(C) Agnihotri and Agnihotri; Licensee Bentham Open.

This is an open access article licensed under the terms of the Creative Commons Attribution Non-Commercial License (http://creativecommons.org/licenses/by$\mathrm{nc} / 3.0 /$ ) which permits unrestricted, non-commercial use, distribution and reproduction in any medium, provided the work is properly cited. 